\title{
Towards Balanced Regional Economic Development: The Case of Saudi Arabia
}

\author{
Abdulkarim K. Alhowaish and Faez S. Alshihri \\ Urban and Regional Planning Department, College of Architecture and Planning, University of \\ Dammam. P.O. Box 2397, Dammam 31451, Saudi Arabia \\ ahowaish@ud.edu.sa
}

\begin{abstract}
Despite all the efforts by Saudi Arabia at all levels to promote balanced regional-economic development across national space, the apparent widening development gap at both inter-and-intra-regional levels still persists. The distribution of population, employment and socio-economic activities in few Saudi regions during the last forty years is also remarkable. The Saudi Arabia, however, realized that unless the trends in polarization of socio-economic opportunities in specific regions and interregional disparities are rectified, Saudi national development cannot be sustained. This research is set to investigate development disparities among regions in Saudi Arabia regarding economic structures and changes over the period of 1992 to 2010. Specifically, this research study attempts to identify the potentialities of economic development in each region of Saudi Arabia and their explicit and implicit competitive advantages to achieve balanced economic development among Saudi regions.
\end{abstract}

\section{Introduction}

Since the early 1970s, the economic development of Saudi Arabia has been broadly guided by five-year national development plans. Their focus has evolved gradually from physical and human development projects to a broader focus on privatization, balanced development, and recently on the notion of sustainability and sustainable development. According to Alhowaish (2011) ${ }^{[1]}$, if one was to summarize the regional development component of the Saudi National Development Plans during the last forty years, one would probably highlight that, since the Third Plan (1980-1985), a primary stated objective of the Saudi government policies has been to expand the opportunities in all regions of the country and to develop their full development potentials in order to achieve a balanced regional development and enhance the living standard and welfare of their population. Currently, the Ninth National Development
Plan (2010-2014) has paid particular attention to the notion of balanced regional development.

According to the Ninth National Development Plan (2010: 10/85), the third national theme, "balanced development among regions of the Kingdom", aims to spread the efforts and fruits of development to all regions in a manner that brings their development to similar levels. To achieve the objectives of this theme, the Plan's programs focus on providing the needed infrastructure and public services in the different regions, based on objective indicators and criteria that reflect the present and future conditions of the regions. The Plan also provides the necessary financial and organizational needs for the development of the production base of each region based on its developmental potential and comparative advantage. The Ninth Plan provides guidance to distribute economic activities among the Kingdom's regions in such a way that would 
avoid concentration of activities in major regions, while achieving maximum efficiency in utilization of available economic resources. Further, the Ninth Plan adopts the following general objectives with regard to regional development:

1. To achieve balanced development among the Kingdom's regions, at levels that would boost their role in socio-economic development.

2. To raise living standards and improve quality of life for all citizens.

Balanced regional development is a real issue facing policy makers, planners and development agencies in Saudi Arabia, this is because, the polarized nature of economic activities as well as population and employment of specific regions is not only remarkable but also persistent over time ${ }^{[1-3]}$. The government recognized that unless past trends in polarization of specific regions and interregional disparities are rectified, national economy cannot be sustained ${ }^{[4,5]}$.

Understanding the complexities of the Saudi national system in terms of regional economic development is an indispensable issue in order to formulate answers to existing and/or new economic challenges facing Saudi national economy. This research paper, therefore, sets to investigate the characteristics of Saudi regions in terms of their economic structure and change during the period of $1992^{[6]}$ and $2010^{[7]}$. In particular, this research study aims to identify the potentiality of economic development in each region of Saudi Arabia and their explicit and implicit competitive advantages. Identifying the regional development potentialities for Saudi regions and their comparative advantages is the first step toward achieving the Saudi national goal of creating "balanced development among regions of the Kingdom". Toward this end, the paper is organized as follows: Part two highlights some literature reviews regarding regional disparities, Part three provides background information about Saudi regions, Part four introduces methodological framework, including data collection and analysis techniques used in this research. Part five discusses empirical results. The last part provides the main findings and conclusions.

\section{Literature Review}

The term disparity refers to differences in rank, conditions or excellence ${ }^{[8]}$. When this term applied to the spatial dimensions of regions or territories, the term disparity can be used to describe the variations in wealth, and socio-economic conditions and opportunities among places ${ }^{[9]}$. However, regional economic disparity refers to differences in unemployment rates, labor force participation, and personal income levels per capita among and between regions ${ }^{[10]}$. Three key characteristics of regional economic disparities have been emerged from the existing literature:

1- Disparities are linked to the natural resources and physical characteristics of the region.

2- Disparities are indicative of an unequal development of production-based potential.

3- Disparities highlight the great differences in income and living standards from one region to another.

These three characteristics of disparity seem to have a high degree of interdependence between them. The presence of rich natural resources will encourage investment; investment will influence the production-based through industrial mix and employment levels; and thereby higher income and standard of living. 
But why do some regions grow rapidly, while others slow down or stagnate? In other words, why do regional disparities exist and persist over space and time? In order to have a better understanding of the mechanisms of regional development and the causes of regional disparities, theories of regional economic development have to be considered. There are a variety of theories that attempt to answer the question of "why" economic development leads to spatial concentration and regional disparities. Among these theories are the neoclassical growth theory, the cumulative causation theory, and the core-periphery theory.

\subsection{Neoclassical Growth Theory}

Neoclassical growth theory is (practically) an adaptation of the standard neoclassical model for a national economy, which expounds that the market mechanism will eventually equilibrate regional differences by free mobility of factors (i.e., automatic equilibrating mechanisms). These two concepts provide a theoretical rationale for interregional per capita income convergence. The convergence in the United States, for example, has been determined empirically by long-term historical studies of the United States economy ${ }^{[11,13]}$. Some of the critical predictions about interregional factor flows may be derived from a simple, comparative static model. The basic assumptions of the model are: full employment, perfect competition, one homogeneous commodity, zero transport costs, regionally identical production functions exhibiting constant returns to scale, a fixed supply of labor and no technical progress.

Given certain simplifying assumptions, the wage is a direct function of the capitallabor $(\mathrm{K} / \mathrm{L})$ ratio while the return to capital is an inverse function of the $\mathrm{K} / \mathrm{L}$ ratio. Under these conditions, labor will flow from lowwage to high-wage regions and capital will flow in the opposite direction. These flows continue until factor returns are equalized in each region. In other words, the movement of factors, namely capital and labor, guarantees a convergence in per capita income. According to Borts and Stein ${ }^{[14]}$, migration of the labor force from low-income regions (with a surplus of available labor) to high-income regions (with a demand for labor) reduces regional disparities in unemployment and income between regions. This migration of workers and their families from poor regions to developed regions reduces the number of workers in the poor regions (e.g. workers in agriculture activities). In the short run, a period in which the stock of capital remains unchanged, this results in an increase of marginal output in the periphery and a reduction in the core region. This, in turn, leads to reduction of interregional income inequality ${ }^{[15]}$.

\subsection{Cumulative Causation Theory}

In his theory of "circular causation," Myrdal criticizes the neoclassic concept of stable equilibrium. "Regional growth is a disequilibrating process. The play of forces in the market normally tends to increase, rather than decrease per capita income inequalities between regions" ${ }^{[16]}$.

An advantage of this theory over neoclassical models is that it places considerable stress on agglomeration economies in rich regions as a cause of divergence. Market forces lead to the clustering of activities with increasing returns to scale in certain areas of the economy. This build-up becomes self-sustaining because of increasing internal as well as external economies at the centers of agglomeration. The limited advantages of lagging or poor regions, such as cheap labor, are insufficient to offset these agglomeration economies. 
The main influence on the growth rate of lagging regions is the induced effects of growth from the developed regions. These effects are of two types: spread (favorable) effects and backwash (unfavorable) effects. The former include markets for the typically primary products of the lagging regions and diffusion of innovation. Normally these are out-weighted by backwash effects, particularly by disequilibrating flows of labor, capital, goods and services from lagging to developed regions.

Hirschman $1958^{[17]}$ wrote in a similar vein as Myrdal. According to Hirschman, once growth begins it tends to concentrate around its initial starting points because of external economies such as lower costs of production, localization of linked firms and expansion of markets. Other regions are affected both in positive and negative ways by development in geographical growth points. Hirschman has called the favorable forces the "trickling down" and the adverse forces the "polarization effects," similar to Myrdal's "spread effects" versus "backwash effects".

Progress at the growth center is "trickled down" to the backward areas because of migration of labor, which decreases the pressure of population and activities in backward areas. On the other hand, a greater ability to compete among industries, better investment opportunities in the developed region, and the removal from backward regions of the best of their resources, all lead to polarization at the growth center and discouraged growth in the hinterland. For Hirschman, the most serious polarization effect is the "brain drain," where the best managers and technicians migrate from the backward regions to the growing centers.

Interestingly, Hirschamn's and Myrdal's conclusions are in contrast to one another. According to Myrdal, in the long-run regional per capita incomes tend to diverge rather than converge due to economies of scale resulting from increasing returns to scale effect continues at the center agglomeration. On the other hand, Hirschman feels that, in the longrun regional per capita incomes tend to converge rather than diverge. This is due to the diseconomies resulting from decreasing returns to scale effect because of the congestion of industries and the insufficient size of the home market ${ }^{[17]}$. This size insufficiency is caused by low income levels in the hinterland, a natural limit, which weakens barriers to free the lowering of factors of production. These diseconomies and the existence of complementaries, as well as government policy, will ensure the extensive spread of development.

\subsection{Core-Periphery Theory}

Friedmann's ,1966 [18] core-periphery model is built on the basis of an understanding of the historical processes of spatial development. Friedmann borrowed from Rostow's idea of the stage theory of economic development [19], and incorporated some aspects of Myrdal's and Hirschman's concepts discussed above, as he developed his coreperiphery model. This model stresses the cumulative and self-reinforcing advantages of the initial location. It stresses that lagging regions normally have limited advantages, which render them insufficient to make up for the lack of agglomeration advantages. The model points out that economic development has the tendency to concentrate in a number of urbanized areas in the beginning and to spread across other regions later on. He argued that there are four phases of national development: pre-industrial, transitional, industrial, and postindustrial. In the first phase (the pre-industrial phase), regional policy will not be very important for national economic growth, since the country will be preoccupied with the basics, such as health and education. In the second phase of national development, when 
the economy is in transition, regional policy is critical.

His core-periphery model was designed to fit the transitional stage of the economy. The transitional economy, he argued, is characterized by a growing core and a lagging periphery with a notion of reinforcement. In the industrial phase of economic development, growth will filter to new centers in the periphery (rural regions), and in the postindustrial phase, the economy will achieve full integration (Full integration in terms of capital, labor, and commodities). According to Friedmann $1966^{[18]}$, the means proposed for reaching this objective (full integration of the national space economy) involves the creation of an urban hierarchy, which spans the effectively settled national territory as well as a national system of market areas for capital, labor, and commodities. The first of these suggests an emphasis on the location and functional role of cities, while, the second points to the creation of an adequate institutional structure that will facilitate the shift for local and regional to a nationwide system of market areas.

Frank,1966 [20] also wrote in a similar vein as Friedmann theory of development. Frank's Metropolis Hinterland Theory is built on the basis of an understanding of the relationship and development process of underdeveloped countries as hinterland and foreign countries as metropolis. This theory starts with the assumption that wealth is concentrated and therefore power is concentrated. Those regions (metropolis) which hold power over other regions (hinterland) use that power to exploit the weaker regions. In the Metropolis Hinterland Theory, the poverty of the undeveloped region of the dual economy is not because it lacks links with the developed region. The poverty is due to those links ${ }^{[21]}$.
To sum-up, classical and neoclassical economists consider regional disparity only a temporary disequilibrium in the economy that the "invisible hand" of the market forces will correct on its own. The experience of both developed and developing countries indicates that economic policies are essential for the improvement of the lagging regions. Writers like Myrdal, Hirschman, Friedmann, Frank and many others have argued that growth does not take place evenly, but rather occurs in a few growth points that usually prosper at the expense of the rest of the country. They also add that market forces, if left alone, tend to reinforce the concentration of development in the growth centers by attracting capital and labor from the backward regions in a search for high return on investment, employment opportunities, better living standards and public services. These writers and many others have convincingly argued that government intervention, through a process of regional development, is not only predictable but also necessary in order to facilitate the spread/trickling down of growth from developed regions to the lagging behind regions.

\section{Saudi Regions: Background Infromation}

A region can be defined in several ways such as: "boundary lines" [22]; "an area whose boundaries are set on the basis of certain criteria" [23]; "different spatial units" [24]; "a set of spatial points" [25]; "a larger administrative or functional area" [26]. While in Saudi Arabia, a region can be define as large administrative area ${ }^{[4]}$. According to Ministry of Economic and Planning report ${ }^{[4]}$, during the fifth development plan period (1990-1995), the five former planning regions were replaced as spatial references for planning by the 13 regions (Map 1), which differ from each other by a host of geographic, demographic and economic factors. 


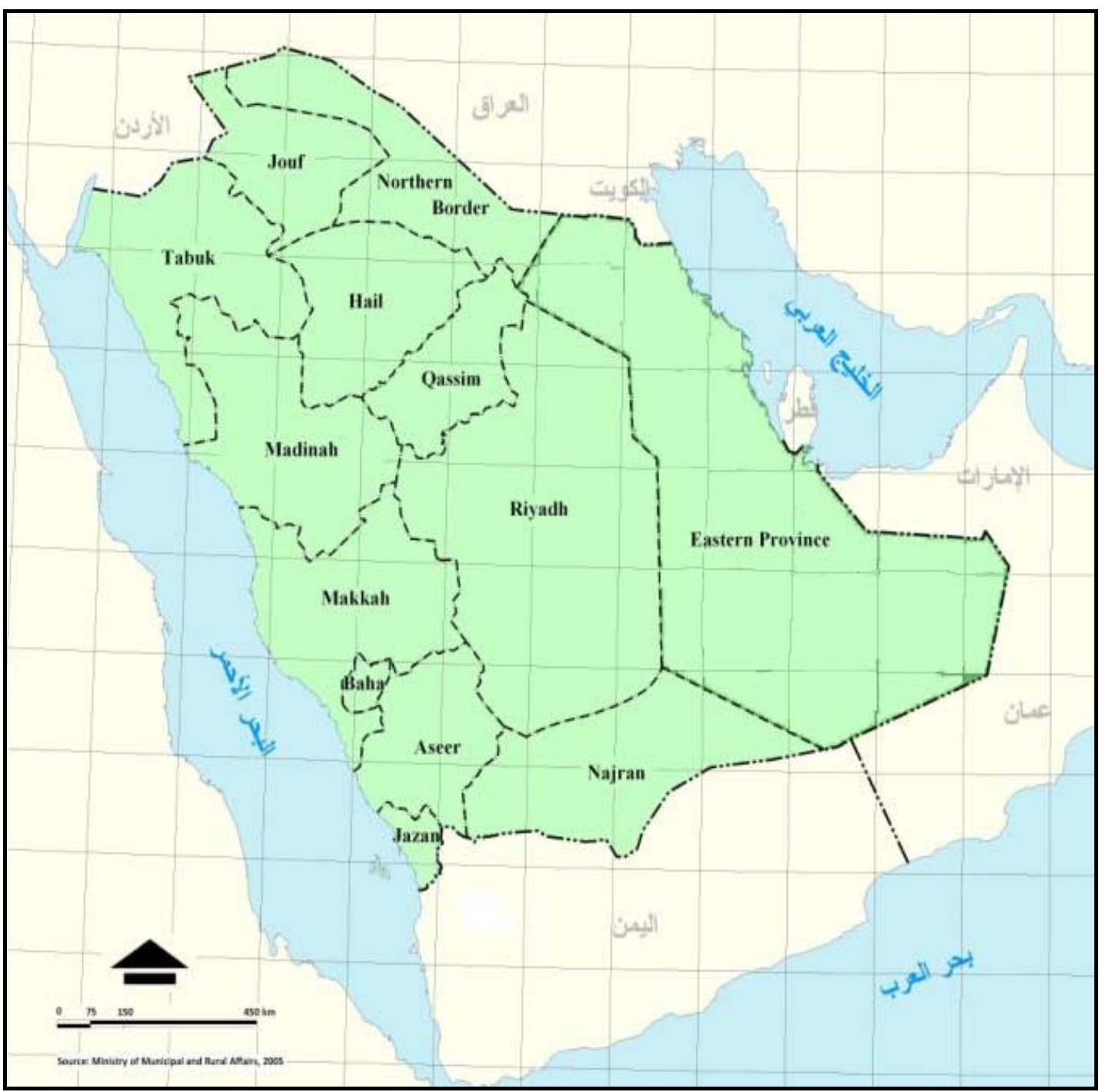

Map 1: Saudi Administrative Regions

Source: Ministry of Municipal and Rural Affairs, 2000. ${ }^{[5]}$

A report study on Saudi regional development characteristics carried out by Ministry of Economic and Planning in 2005 highlighted the following characteristics of Saudi regions:

- Three regions; namely, Riyadh, Makkah and the Eastern region, have witnessed high population growth over the successive development plans mainly due to internal migration. Together, these regions comprised $64.5 \%$, or almost two thirds, of the total population in 2004 .
- Internal migration was not restricted to migration between regions but also included migration from rural areas to urban areas within individual regions, leading to the concentration of population in the major cities. In 2004, the ratio of the population of the two biggest cities of a region to its total population was almost $82 \%$ for Riyadh region, $85 \%$ for the Northern Border, $82 \%$ for $\mathrm{Al}$ Madinah, $78 \%$ for Tabuk and $73 \%$ for Makkah region.

- The geographical distribution of economic activity is in line with population distribution, 
being highly concentrated in the Riyadh, Makkah and Eastern regions. In 2003, of the total number of operating business firms $(570,000) 30 \%$ were located in the Riyadh region, $28 \%$ in the Makkah region and $16 \%$ in the Eastern region; a total of $74 \%$.

- The regional distribution of industrial activities is highly uneven across Saudi regions. For instance, the average number of industrial jobs per 10,000 people ranges from 237 in the Riyadh region to only 7 in the Northern Border region.

The report concluded that, regional disparity in Saudi Arabia is mainly attributable to the unbalanced distribution of the productive sectors and hence employment opportunities. The report also added that achieving balanced development across all regions requires not only the providing physical infrastructure and basic services, but also synchronously creating a production base primarily based on the development potentialities of each region and implementing a national strategy that encourages and directs investments and activities to the regions in needs ${ }^{[27]}$.

\section{Methodological Framework}

\subsection{Research Data}

In order to identify regional development potentials and their comparative advantages, the study and analysis will cover all the 13 regions in the country in terms of their population, employment, and economic activities over the period of 1992 and 2010 (see Map 1). The regions are as follows:

$\begin{array}{lll}\text { 1- Riyadh } & \text { 6- Qassim } & \text { 11- Baha. } \\ \text { 2- Makkah } & \text { 7- Jazan } & \text { 12- Jouf } \\ \text { 3- Eastern Province } & \text { 8- Tabuk } & \text { 13- Northern Borders } \\ \text { 4- Aseer } & \text { 9- Hail } & \\ \text { 5- Madinah } & \text { 10- Najran } & \end{array}$

Data on regional population, employment and economic activities were obtained directly from Central Department of Statistics and Information database. The data were available in electronic form, allowing more efficient analysis. Data on economic activities were aggregated into 16 sectors (Table 1). These sectors were grouped into three broad sectors:

\subsection{Research Techniques}

To better understand the current state of Saudi regional economies including their complexities and their relative strengths and weaknesses, a detailed analysis of current and past performance of regional economy must be performed. There are numerous methods and techniques that have been developed by economic development scholars to analyze regional economies and help economic development planners and practitioners understand important economic trends in the regional economy. One of these methods is the economic base analysis techniques. As suggested by many researchers [28-34], economic base analysis is the preferred method among economic development specialists for understanding the characteristics of regional economies. It is a simple yet valuable tool that can be used to gain an understanding of the economic structure of regions and their relative strength and weaknesses. It can provide comparative information on the economic status of localities across time periods with respect to employment conditions and trends.

Economic base analysis assumes that the regional economic structure can be divided into two main sectors: basic and non-basic. Economic base analysis is grounded on the premise that basic industries form the base of regional economic structure, and all other industries flourish by servicing this sector. Through its non-local market sales and resulting injection of new money into the local economy, the basic sector is an important contributor to and driver of regional economic growth and development. Changes in the 
composition or performance of the basic sector usually impact the non-basic sector and overall trends in the regional economy.

Economic base analysis technique has shown that a regional economy is strongest when it develops those economic sectors that bring new money into the regional economy. Although there are several approaches to estimate the regional economic base, the location quotient (LQ) approach is the most popular method ${ }^{[31,32]}$. A major objective for calculating Location Quotients is to identify those industries that constitute the region's economic base and export-oriented sector(s). Location Quotient is the ratio of an industry's share of the regional employment divided by its share of the reference area (the nation). The formula for computing location quotients can be written as:

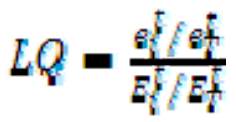

Where:

$e_{i}^{t}=$ Regional employment in industry $i$ at time $\mathrm{t}$

$\epsilon_{7}^{*}=$ Total regional employment at time $\mathrm{t}$

$E_{i}^{\varepsilon}=$ National employment in industry $i$ at time $\mathrm{t}$

$E_{T^{\prime}}^{*}=$ Total national employment at time $\mathrm{t}$

The focus of Location Quotient calculations is primarily the identification of those sectors that have an LQ exceeding 1.00. A location quotient greater than one (LQ $>1$ ) indicates that employment for an industry is more highly concentrated in a region than elsewhere in the country. Highly concentrated employment indicates firms in that region have a comparative advantage than similar firms in other regions in the country. From an economic development standpoint the Location Quotient indicates the nature, diversity and concentration of economic activity in a region. Where diversification of the economic base is a desired goal, LQs indicate which sectors of the regional economy have greater concentrations of employment, more comparative advantage and which sectors might be targeted for indigenous expansion or firm relocation recruitment efforts. However, just because a region has a large LQ does not necessarily mean there is, or will be, job growth in the future. It only means that on a relative basis this sector plays a significant role in the region's export base. Industries with high LQs do not always employ large numbers of workers, nor do they necessarily display net employment growth. Policy makers and development planners would like to see their region becoming more stable and economically strong due to high employment concentration (i.e. exportoriented) and the workforce is increasing due to expanding product demand and exports from the region. Therefore, both the LQ and the change in workforce (i.e. growth/decline) are used to better understand the dynamic changes (strengths and/or weaknesses) of Saudi regional economic structures over time. Both the LQ and change in regional workforce can be categorized into four types (Fig. 1):

1- Type I: economic activity with high Location Quotient (LQ) and net employment growth rate (E.gr) above the national average (i.e. LQ $>1$ \& E.gr. $>$ National Av.)

2- Type II: economic activity with high LQ and net employment growth rate below the national average (i.e., LQ $>1$ \& E.gr. $<$ National Av.).

3- Type III: economic activity with low LQ (i.e., less than or equal one) and net employment growth rate above the national average (i.e. LQ $<1$ \& E.gr. $>$ National Av.).

4- Type IV: economic activity with low LQ and net employment growth rate below the 
national average (i.e., LQ $<1$ \& E.gr. $<$ National Av.).

A high location quotient and positive net employment growth in a specific sector may translate into a competitive advantage in that sector for the regional economy. Policy makers and development planners should focus on these sectors for future growth and prosperity. These sectors are the engine of economic growth in the regional economy.

Table 1: Classification of Economic Activities.

\begin{tabular}{cl}
\hline \multicolumn{1}{c}{ Sector } & \multicolumn{1}{c}{ Economic Activities } \\
\hline Primary Sectors & 1- Agriculture, Hunting, Forestery \& Fishing \\
& 2- Petroleum \& Minerals \\
\hline Secondary Sectors & 3- Manufacturing \\
& 4- Electricity, Gas \& Water \\
& 5- Construction \\
\hline Tertiary Sectors & 6- Trade (Wholesale \& Retail) \\
& 7- Tourism (Restaurants \& Hotels) \\
& 8- Transportation, Storage \& Communication \\
& 9- Banking \& Insurance \\
& 10- Real Estate \& Business Services \\
& 11- General Administration \\
12- Education Services \\
13- Health Services \\
14- Community \& Social Services \\
15- Private Households Services \\
16- International Organizations Services \\
\hline
\end{tabular}

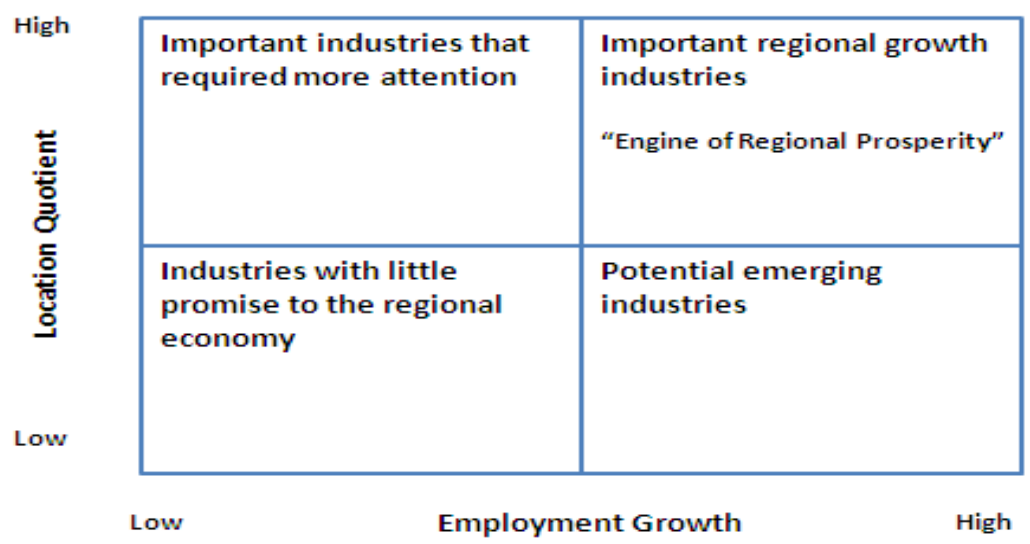

Fig. 1. Typology of Regional Economic Activities.

\section{Empirical Analysis}

Between 1992 and 2010, population in the Kingdom increased by 60 percent. This is an absolute increase of 10.1 million people. All thirteen regions in the Kingdom reported population growth during this period. Riyadh region had the greatest increase in population (77 percent) followed by Najran region (68 percent), Jouf and Madinah regions (64 percent) each, Tabuk region (63 percent) and Qassim region (62 percent). These six regions reported population growth above the national average. For other seven regions, all reported population growth below the national growth rate. Population in Eastern Province increased by 59 percent, Jazan by 58 percent, Makkah by 55 percent, Hail by 45 percent, Aseer by 43 
percent, Northern Border by 40 percent, and Baha region with the lowest population gains of about 24 percent over this 18-year period (Fig. 2). In 1992, Riyadh, Makkah and Eastern Province were among the largest regions in the Kingdom. They remain so today. In 2010, about 17.8 million populations lived in these three regions, which represented 66 percent of the Saudi total population. This was an increase from 64 percent in 1992. The remaining regions reported a population share ranging from 8 percent as in the case of Aseer region to 1 percent as in the case of Northern Border in 1992 with no/or slight change in their population shares during the 2010 period (Appendix 1).

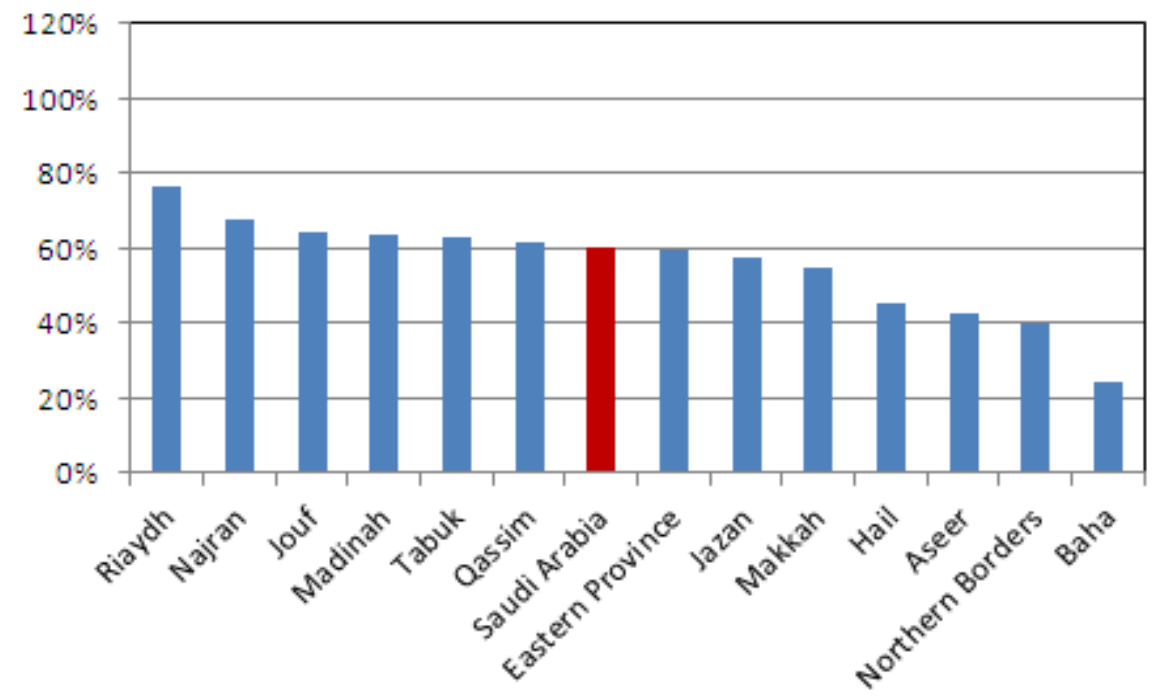

Fig. 2. Saudi Regional Population, 1992 to 2010.

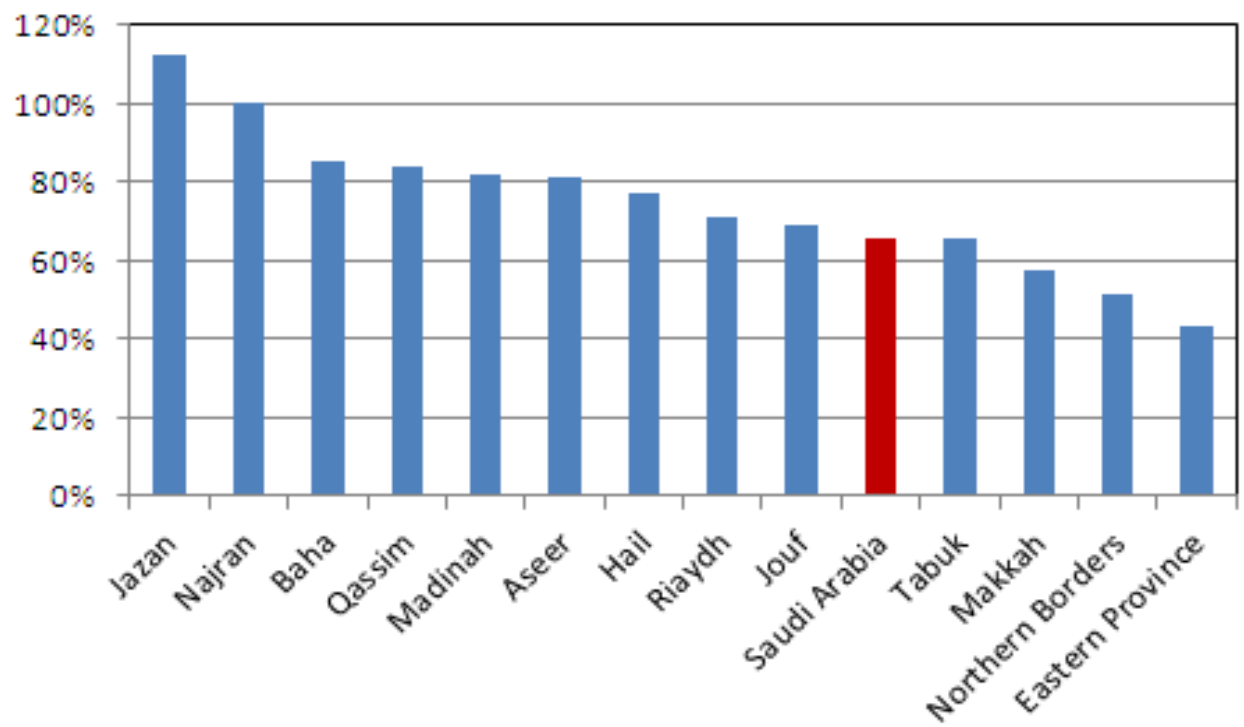

Fig. 3. Saudi Regional Employment, 1992 to 2010. 


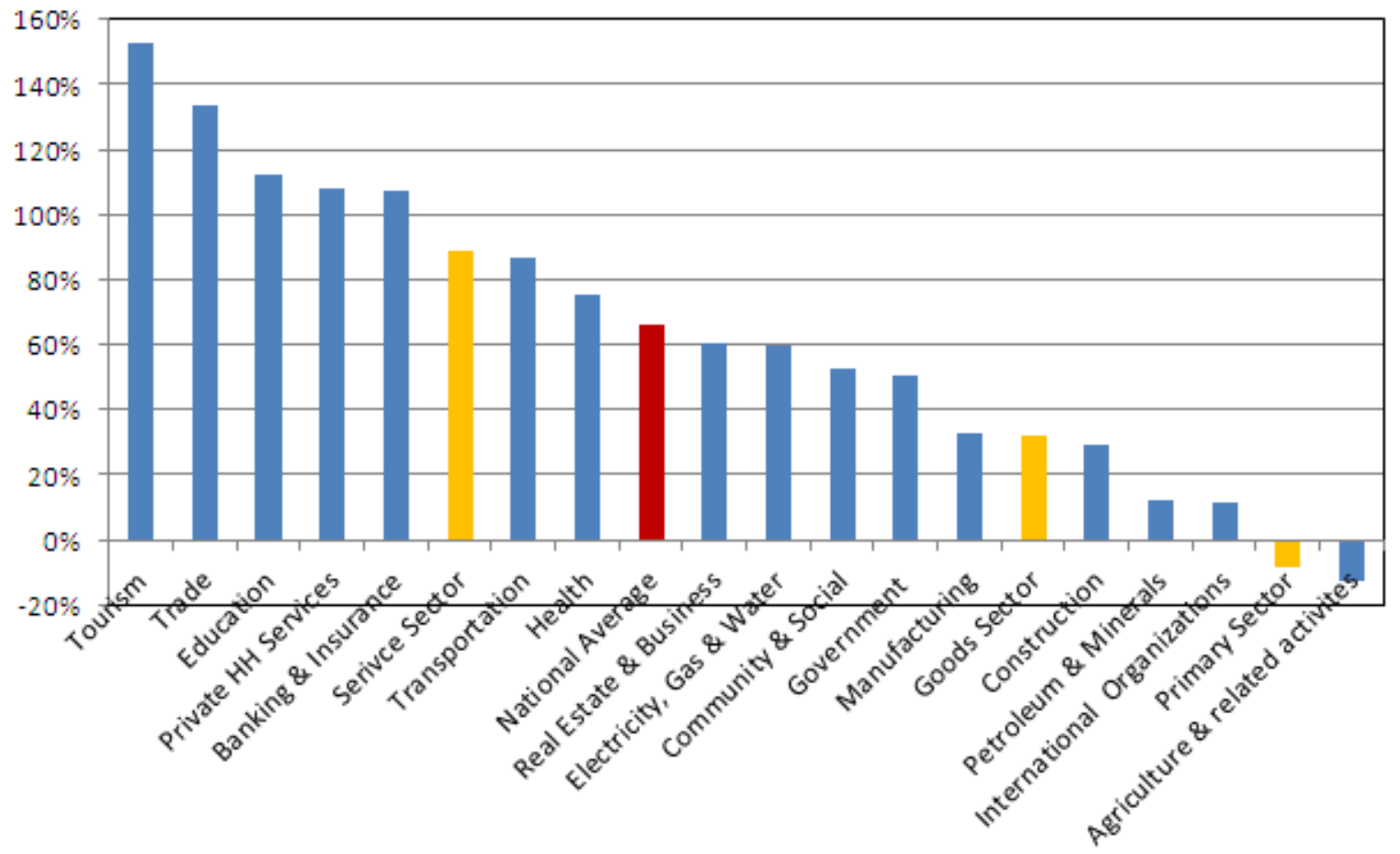

Fig. 4. Regional Economic Sectors, 1992 to 2010.

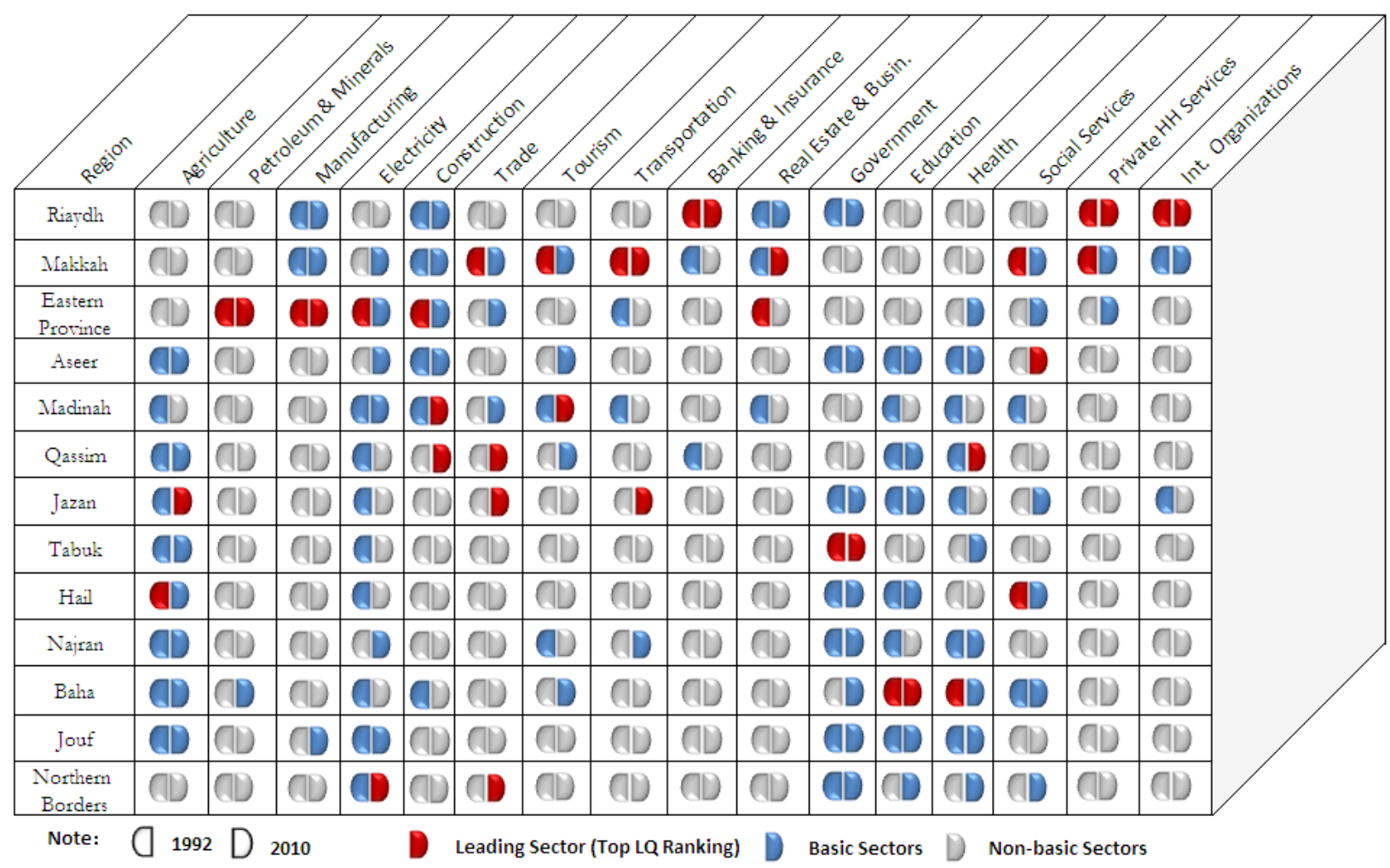

Fig. 5. Saudi Regions and their LQ Results, 1992 and 2010. 
Employment figures displayed a different picture than the population data over the same period of analysis. At national level, the Kingdom employment figures experienced an increase of 66 percent or an absolute employment increase of 3.2 million workers during the 18-year period. Riyadh (29 percent) and Makkah (24 percent) regions together represented more than half (53 percent) of the total Saudi employment gain during this period. By 1992, these two regions employed a total of 2.6 million workers or 55 percent of Saudi workforce, and by 2010 , these regions employed a total of 4.4 million workers or 54 percent of the national employment. This was followed by Eastern Province region "the third largest region in the Kingdom," which represented about 12 percent of national workforce gain. The remaining regions represented an employment gain ranging from 7 percent as in the case of Madinah and Aseer regions to 1 percent as in the case of Northern Border and Jouf regions, respectively. The analysis of Saudi regional employment also revealed that nine regions (69 percent) out of thirteen regions reported employment growth rate above the national average rate (Fig. 3). Jazan region tended to exceed the national employment growth rate by more than (47 percent) followed by Najran region (35 percent), Baha (20 percent), Qassim (18 percent), Madinah (16 percent), Aseer (15 percent), Hail (11 percent), Riyadh (5 percent), and Jouf (3 percent). Tabuk region went slightly below the national employment growth rate by 0.3 percent, while the employment growth rate for Makkah, Northern Border and Eastern Province regions went below the national workforce average by 8 percent, 14 percent and 22 percent respectively (Appendix 2).

The scenario above depicts that Saudi economic structure is quickly changing. As in most developing countries, primary sector in Saudi Arabia is losing jobs while the tertiary sector is employing more people every year. Tertiary sector employed a total of 6.1 million persons or more than 75 percent of the total workforce in 2010. This was an increase from 66 percent in 1992. Employment in primary sector dropped from 9 percent in 1992 to less than 5 percent in 2010. Similarly, employment share in goods sector dropped from 24 percent in 1992 to 19 percent in 2010. Over the 18year period, the service sector as a whole increased by 89 percent, which represents an absolute increase of 2.8 million jobs. The goods sector as a whole increased by 32 percent or an absolute increase 382 thousand jobs, while, the primary sector as a whole lost about 8 percent or an absolute decline of more than 38 thousand jobs.

For individual economic sectors, however, seven economic sectors reported employment growth above the national employment growth rate during the 1992 and 2010 period (Fig. 4). The largest increases in terms of job opportunities were in: (1) trade (wholesale and retail) which added 801 thousand jobs (134 percent); (2) education services added 469 thousand jobs (113 percent); (3) personal and household services added 407 thousand jobs (108 percent); (4) transportation (storage and communication) added 174 thousand jobs (87 percent); (5) tourism (hotels and restaurants) which added 147 thousand jobs (153 percent); (6) health 
services added 142 thousand jobs (76 percent); and (7) banking and insurance services added 50 thousand jobs (107 percent). These seven sectors brought about 2.1 million new jobs, and comprising almost 70 percent of the new total regional jobs. These industries seemed to be gaining momentum in employment opportunities in the regional workforce (Appendix 3). Government service (public administration) is the biggest sector in terms of employment in Saudi Arabia, with an employment of 1 million workers in 1992 to more than 1.5 million workers in 2010 . Equally large is trade (wholesale and retail) sector, employing 600 thousand workers in 1992 to about 1.4 million in 2010. The third major sector is construction, with an employment of 744 thousand in 1992 and about 964 thousand workers in 2010.

The above structural pattern of economic activities is not replicated in all regions in the country. Only three regions (Makkah, Madinah and Eastern Province) followed the same pattern of national economic structure. Government services, trade and construction sectors were the top three sectors for employment in these three regions during the 1992 and 2010 period. In 1992, agriculture sector ranked as the top or second top sector for employment in six regions: Hail, Jazan, Qassim, Jouf, Aseer and Najran, with an employment share of 24 percent, 22 percent, 17 percent, 16 percent, 15 percent and 13 percent respectively. In 2010, however, agriculture sector was replaced by educational service as the second top sector in these regions. In fact, educational sector is one of the five major sectors in all the thirteen regions during the 1992 and 2010 period.

In order to understand the economic structure of the regions and their relative strength and weaknesses over time Location Quotient (LQ) method is used. The primary purpose of using the LQ is to identify those economic sectors that constitute the economic base in each region and which economic sectors have a comparative advantage than similar sectors in other regions in the country. In 1992, the LQ for the thirteen regions clearly indicates that, the majority of the regions were specialized in agriculture and electricity sectors, with LQ greater than 1. This was followed by education service sector. While in 2010, the specialization sector(s) for the majority of regions moved to government service (public administration), followed by agriculture and health sectors. Figure 5 summarized the results of LQ calculations for the thirteen regions in terms of basic, nonbasic and leading sectors with top LQ ranking among regions during the 1992 and 2010 period.

It is worth mentioning that highly concentrated employment indicates that firms or sectors in a region have a comparative advantage than similar firms or sectors in other regions in the country. A comparison among Saudi regional economic sectors in terms of their concentrated employment over time indicates that:

1- Riyadh region has highly concentrated employment in three sectors (banking and insurance; personal household services and international organizational service) in both 1992 and 2010.

2- Makkah region has employment concentration in transportation (wholesale and retail) sector in both 1992 and 2010, followed by real estate and business service sector in 2010 only.

3- Eastern Province shows employment concentration in two sectors (petroleum and 
minerals; and manufacturing sectors) in both 1992 and 2010.

4- Tabuk region shows employment concentration in government service (public administration) in both 1992 and 2010.

5- Aseer region had employment concentration in community and social service sector in 2010 only.

6- Madinah region had employment concentration in construction and trade (wholesale and retail) sectors in 2010 only.

7- Qassim region shows employment concentration in construction; trade (wholesale and retail) and health sectors in 2010 only.

8- Jazan region shows employment concentration in agriculture and related service; trade (wholesale and retail) and transportation (storage and communication) sectors in 2010 only.

9- Comparing with other regions, Hail, Najran and Jouf regions showed no employment concentration in their economic sectors in both 1992 and 2010. The exception was Hail region which had a high employment concentrated in agriculture and related service and community and social service sectors in 1992 only.

Earlier, it was noted that just because a region has a large LQ does not necessarily mean there is, or will be, job growth in the future. It only means that on a relative basis this sector plays a significant role in the regional economic base. Economic sectors with high LQs do not always employ large numbers of workers, nor do they necessarily display net employment growth. High sectoral LQs might not be a desirable outcome if the overall employment in that sector is declining. However, based on four types of LQs and employment growth rate, which has been mentioned early in the research, both the 2010 LQs and change in sector employment between 1992 and 2010 for each region was compared. It has also been mentioned that most regions would likely prefer the situation found in Type I, where their economic sectors are becoming more stable and economically strong due to high employment concentration (i.e., export-oriented) and the workforce is increasing due to expanding product demand and exports from the region. Policy makers and development planners should focus on these sectors for future growth and prosperity. These sectors are the engine of economic growth in the regional economy. While of the sixteen economic sectors, only seven (44 percent) sectors can be classified as the engine of growth for Saudi regional economies (i.e. Type I). These seven sectors shows high LQ and their employment growth rate were above the national growth rate during the1992 and 2010 period. Health sector was the growth engine for eight regions, followed by education sector (7 regions); trade sector (6 regions); tourism sector (5 regions); transportation sector (3 regions); personal household sector (2 regions) and banking and insurance sector for one region only. Across the thirteen Saudi regions, however, Qassim region experienced the strongest economic structure with 25 percent of its economic sectors found to be within "Type I" sectors. Four sectors (health, education, trade and tourism) were the growth engine of Qassim regional economy. This was followed by six Saudi regions (Makkah, Madinah, Aseer, Northern Border, Jazan and Baha regions) with three economic sectors (19 percent) constituted their economic bases. These economic sectors were: (1) transportation, tourism and trade sectors for Makkah region; (2) tourism, trade and personal household service for Madinah regions; (3) tourism, education and health for both Aseer and Baha regions; (4) trade, education and health for Northern Border; and (5) transportation, trade and education sectors for Jazan region. In 
addition, Riyadh region (banking and insurance \& Personal household); Eastern Province (trade \& health); Najran region (health \& transportation), and Jouf region (health \& education) with only two sectors (13 percent) constituted their regional economies. However, only one sector (6 percent) of Tabuk and Hail regional economic structure constituted their economic bases (i.e. health and education sectors), respectively (Appendix 4).

Type II - economic sectors that show high LQ and workforce growth rate below the national workforce growth rate. Sectors within this category can be classified as important sectors that may require more attention in terms of future development policies and strategies. Policy makers and development planners should pay more attention to these sectors for future regional economic development. Of the sixteen economic sectors, nine (56 percent) are found within this type. Among these sectors, however, government service (public administration) classified as an important sector for nine regions. This is followed by agriculture and electricity sectors (7 regions); social and community service sector (6 regions); construction sector (5 regions); manufacturing sector (4 regions); petroleum and minerals sector and international organization service (2 regions) each. Across the thirteen regions, however, six out of these "Type II" sectors constitute the economic structure of Makkah region, followed by Riyadh and Eastern Province with 5 sectors, Aseer and Jouf regions with 4 sectors, Northern Border, Najran, Jazan and Baha regions with 3 sectors, and finally Madinah, Qassim, Tabuk and Hail regions with only 2 sectors.

Type III - economic sectors that show low LQ and workforce growth rate above the national average. Sectors within this category can be classified as emerging potent sectors.
Exactly half (50 percent) of sixteen economic sectors have been found within this type. Among these sectors, however, banking and insurance sector classified as potential emerging sectors for all regions except Riyadh region, followed by personal and household service sector for all regions except Riyadh and Madinah regions; transportation (storage and communication) sectors for all regions except Makkah, Jazan and Najran regions; tourism (8 regions); trade (7 regions); education (6 regions); health (5 regions); government services and petroleum and minerals sectors for one region each. Makkah, Tabuk and Hail regions reported the highest number of sectors to be within this "Type III" category. Six sectors (38 percent) of their regional economic sectors shows low LQ and workforce growth rate below the national average. This is followed by Riyadh, Eastern Province and Jouf regions with five sectors (31 percent); Madinah, Aseer, Northern border, Jazan and Baha regions with 4 sectors (24 percent); and Qassim region with only 3 sectors (19 percent) fall within this type of sectors.

Type IV - economic sectors that show low LQ and workforce growth rate below the national average. Sectors within this category can be classified as sectors with little promise to the regional economy. Policy makers and development planners should not depend on these sectors for future regional growth and development. Paying much attention to these sectors is just as spending your regional development efforts in an empty circle. Of the sixteen economic sectors, however, nine (56 percent) sectors have been found within this type. International organizations service, real estate and petroleum and minerals are among these sectors that shows little promise to the Saudi regional economies. This is followed by manufacturing sector ( 9 regions); construction (8 regions); social and community services (7 
regions); agriculture and related activities and electricity sectors (6 regions) each; and finally government service for only three regions. Across regions, however, Madinah, Qassim, Tabuk and Hail regions reported seven sectors which represented about 44 percent of their economic sectors are found within this type, followed by Northern Border, Jazan, Najran and Baha regions with six sectors (38 percent); Aseer and Jouf regions with five sectors (31 percent); Riyadh region with four sectors (25 percent); and Makkah region with only one sector (6 percent) fall within this type.

\section{Conclusions}

This research paper has attempted to investigate the characteristics of Saudi regions in terms of their economic structures and changes during the period of 1992 and 2010. In particular, the purpose is to identify the potentiality of economic development in each region of Saudi Arabia and their explicit and implicit competitive advantages. Regional population, employment and economic activities data have been used to fulfill the research purpose.

Empirical results, however, show that the population in the Kingdom increased its population by 10.1 million people and employment increased by 3.2 million workers during the 1992 and 2010 period. Riyadh, Makkah and Eastern Province regions captured 68 percent of the national growth in population and about 65 percent in employment. These three regions with a larger population in 1992 are likely to take advantage of agglomeration economies and industry linkages, which reflect the nature of their economic structures. The economic structure of these three regions is characterized by high LQs in most of their economic sectors and growing workforce. Banking and insurance sector; tourism and related activities; and trade (wholesale and retail) sector are the top LQ ranking and the highest employment growth for Riyadh, Makkah and Eastern Province regions, respectively. These three regions can be classified as the "leading" or "developed" regions.

Conversely, six regions (Hail, Tabuk, Najran, Baha, Jouf and Northern Border) are the "least developed" regions. These six regions have captured about 10 percent of the national growth in both population and employment. The economic structure of these regions is characterized by low LQs in most of their economic sectors (i.e. more than 70 percent of their sectors with LQ less than one) and the workforce grew below the national average (i.e. more than 56 percent of sectoral workforce grew below the national average). With the exception of two regions, agriculture and related activities sector ranks as the top LQ sector or second sector in most of these regions, an industry group which declined by more than 8 percent over the period of analysis. The reaming four regions (Madinah, Aseer, Jazan and Qassim) captured about 22 percent of the national population growth and about 24 percent of employment growth. One could classify these regions as "emerging" or "developing" regions. Broadly, a mix of economic sectors is strongly present in these regions, with education sector ranking as the top LQ sector and the highest employment generator in all regions. The analysis also revealed that between 1992 and 2010 seven sectors (trade, education, personal and household, transportation, health and banking and insurance services) experienced employment growth above the national employment growth rate. These seven sectors brought about 2.1 million new jobs to the Saudi regional economies over this period. In spite of these sectors' rapid employment growth, "least developed" regions obtained only 9 percent of this increase, while "leading" and "emerging" regions obtained about 65 
percent and 25 percent respectively. Table 2 summarized the development potentials for the three types of Saudi regions in terms of their explicit (i.e., Type I sectors) and implicit (i.e., Type II sectors) competitive advantages.

Table 2. Summary of Saudi Regional Development Potentials and their Comparative Advantages.

\begin{tabular}{|c|c|c|c|c|c|}
\hline \multirow{2}{*}{ Typology } & \multirow{2}{*}{ No. } & \multicolumn{2}{|c|}{ Share of National Growth } & \multicolumn{2}{|c|}{ Comparative Advantages } \\
\hline & & Population & Employment & Explicit & Implicit \\
\hline $\begin{array}{l}\text { Leading } \\
\text { Regions }\end{array}$ & 3 & $68 \%$ & $65 \%$ & $\begin{array}{l}\text { 1. Banking and Insurance } \\
\text { 2. Trade } \\
\text { 3. Tourism } \\
\text { 4. Transportation, Storage \& } \\
\text { Communication } \\
\text { 5. Personal \& HH Services }\end{array}$ & $\begin{array}{l}\text { 1. Petroleum and Minerals } \\
\text { 2. Manufacturing } \\
\text { 3. Real Estate and Business } \\
\text { 4. Construction } \\
\text { 5. International Organizations }\end{array}$ \\
\hline $\begin{array}{c}\text { Emerging } \\
\text { Regions }\end{array}$ & 4 & $22 \%$ & $24 \%$ & $\begin{array}{l}\text { 1. Education } \\
\text { 2. Tourism } \\
\text { 3. Health } \\
\text { 4. Trade }\end{array}$ & $\begin{array}{l}\text { 1. Government Services } \\
\text { 2. Social Services }\end{array}$ \\
\hline $\begin{array}{c}\text { Least } \\
\text { Developed } \\
\text { Regions } \\
\end{array}$ & 7 & $10 \%$ & $11 \%$ & $\begin{array}{l}\text { 1. Education } \\
\text { 2. Health }\end{array}$ & $\begin{array}{l}\text { 1. Government services } \\
\text { 2. Electricity, Gas and Water } \\
\text { Services }\end{array}$ \\
\hline Total & 13 & $100 \%$ & $100 \%$ & 7 & 8 \\
\hline
\end{tabular}

To sum up, promoting balanced regional economic development across Saudi regions has been a key objective of national socioeconomic development ever since the Third National Development Plan was initiated some thirty years ago. However, the efforts made by Saudi governments at all levels to rise to the challenge of balanced economic development across the regions, through providing basic socio-economic development requirements, such as basic infrastructure and public services, in all regions, considerable regional disparities persist; a matter that constitutes a challenge for the ninth and perhaps the tenth national development plans to deal with.

Providing public services (e.g. education, health and government services) and constructing infrastructure projects (e.g. major highways, railways, electricity and water supply system) across Saudi regions as a key principle in achieving balanced regional economic development does and will not solve the problems of Saudi regional disparities. The provisions of basic socio-economic development across regions may, in fact, result in reducing the level of regional service-base disparities but not the production-base disparities. If the challenge of creating balanced regional economic development is reduced to mean service-base provision only, then the outcome will leave the core of the challenge untouched. Stimulating the production-base activities especially in the least developed regions through their particular spatial development potentials and their comparative advantages will indeed solve the problem of Saudi regional economic disparities and, at the same time, achieve the long-term national goal of creating "balanced regional development" across Saudi regions.

The problem regions (the least developed regions) are defined as such because on the one hand they have resources that are not fully exploited and/or recognized, and on the other hand they have lower growth rates compared to the rest of the nation. What is required is not merely a re-distributive policy to minimize regional differences in the standard of living. The unused/under-used regional development potentials need to be a 
primary objective of the future Saudi regional policies.

This research study, therefore, recommended that policy-makers, planners and development agencies should work together to transforming the comparative advantages of each region, which have been identified in this study, into competitive advantages and, at the same time, creating policies and strategies to direct investments towards the least developed regions. This will eventually lead to reduce disparities in economic activities and levels of employment; and thereby income and living conditions among regions.

Finally, this study underscores the indispensable need for further studies and commensurate actions in respect of balanced development in social and environmental fields involving infrastructure development towards inter-regional and intra-regional connectivity and rural-regional accessibility, settlement development and quality of life etc. These are the imminent tasks in ensuring sustainability and sustainable regional development, and as such should be taken up earnestly. Future studies might also examine a wider variety of characteristics to more adequately reflect other aspects of regional disparity. For instance, one might want to include income and GDP along with employment in a more comprehensive set of indicators to measure regional disparity. Extending the analysis to characteristics such as family structure, culture, housing, political administrations and provincial and local (municipal) councils would provide insights on the changing economic and social nature of Saudi regions.

\section{References}

[1] Alhowaish, A.K. (2011), "Development Policies for Economic Diversification vs. Economic Specialization: the Case of Saudi Urban Economies," Journal of Development and Economic Policies, 12(2): 57-72.
[2] Alankary, K. M. and Elbushra, S. (1989), Urban and Rural Profiles in Saudi Arabia. Gebruder Brontraeger, Berlin, Stuttgart, Germany.

[3] Alhathloul, S. and Edadan, N. (1995), Urban Development in Sauda Arabia: Challenges and Opportunities. Dar Al-Salam: Riyadh

[4] Ministry of Planning (1995), Regional and Urban Development: Key Issues in Regional Development. Ministry of Planning (MOP) Press, Riyadh, Saudi Arabia, Chapter 15: 370.

[5] Ministry of Municipal and Rural Affairs (2000), National Spatial Strategy for Saudi Arabia: An Overview. Ministry of Municipal and Rural Affairs (MOMRA) Press, Riyadh, Saudi Arabia.

[6] Central Department of Statistics and Information (1992), Socio-economic Indicators, Ministry of Economic and Planning Press, Riyadh, Saudi Arabia.

[7] Central Department of Statistics and Information (2010), Socio-economic Indicators, Ministry of Economic and Planning Press, Riyadh, Saudi Arabia.

[8] Merriam-Webster (1995) Merriam Webster's Collegiate Dictionary, Meriam-Webster Incorporated: US.

[9] Alasia, A. (2002) "Regional Disparities in Predominantly Rural Regions". The Canadian rural revitalization foundation, Ontario, Canada.

[10] ADAMS, John (2004) "Tackling Regional Disparity", New Economy: U.K.

[11] Easterlin, R. A. (1958) "Long Term Regional Income Changes: Some Suggested Factors," Paper of the Regional Science Association, 4: 313-325.

[12] Romans, J. T. (1965), Capital Exports and Growth Among U.S. Regions, Wesleyan University.

[13] Dunn, R. (1987) "Analyzing Spatial the Series of Local Unemployment: A Graphical Approach Using Principle Components Analysis and Seasonal Adjustment Procedures," Environment and Planning A, 19: 225-246.

[14] Borts, G. L. and Stein, J. L. (1964), Economic Growth in a Free Market, New York: Columbia University Press.

[15] Lipshitz, G. (1995) "Regional Disparities: the Canadian Case in the Theoretical Context." Canadian Journal of Regional Science, (Autumn, 1995): 357-378.

[16] Myrdal, G. (1957), Economic Theory and UnderDeveloped Regions, Methuen: University Paperbooks.

[17] Hirschman, A. O. (1958), The Strategy of Economic Development, New Haven: Yale University Press.

[18] Friedmann, John. (1966), Regional Development Policy: A Case Study of Venezuela, Camridge: The MIT Press. 
[19] Rostow, W. W. (1961), The Stages of Economic Growth, ${ }^{1 s t}$ Ed, Cambridge: Cambridge University Press.

[20] Frank, A. G. (1966) "The Development of Underdevelopment," Monthly Review, 18(4).

[21] Bradfield, M. (2002), Regional Economics Analysis and Policies in Canada, McGraw-Hill Ryerson Limited.

[22] Kaldor, N. (1970) "The Case for Regional Policies," Scottish Journal of Political Economy, 17: 337-348.

[23] Firestone, O. J. (1974) "Regional Economic and Social Disparity," In: O. J. Firestone, Regional Economic Development, Ottawa: University of Ottawa Press: 205268.

[24] Rao, H. (1984) "Regional Disparities and Regional Planning," In: Rao, H., Regional Disparities and Development in India, New Delhi: Ashish Publishing House. 1-47.

[25 Biehl, D. (1980) "Determinants of Regional Disparities and the Role of Public Finance," Public Finance, 35: 4471 .

[26] OECD (1994), Creating Rural Indicators for Shaping Territorial Policy, OECD, Paris.

[27] Ministry of Economic and Planning (2005), Regional Development: Key Issues in Regional Development.
Ministry of Planning (MOP) Press, Riyadh, Saudi Arabia, Chapter 10: 193-205.

[28] Rupasingha, A. and Patrick M. (2009), Tools for understanding economic change in communities: Economic Base Analysis and Shift-Share Analysis, NM State University, Las Cruces - Circular 643A: August 2009.

[29] Blakely, E.J. and Bradshaw, T.K. (2002), Planning Local Economic Development: Theories and Practice, $3^{\text {rd }}$ edition, Thousand Oaks, CA: Sage Publication, Inc.

[30] Siegel, P.B., Alwang, J. and Johnson, T.G. (1995) "Regional economic diversity and diversification," Growth and Change, 26: 261-284.

[31] Ben-David, A. (1991), Regional and Local Economic Analysis, $4^{\text {th }}$ (Ed.), New York: Praeger Press.

[32] Malizia, E.E. (1990) "Economic growth and economic development: Concepts and measures," Review of Regional Studies, 20: pp. 30-36.

[33] Hoover, E.M. and Giarratani, F. (1985), An Introduction to Regional Economics, $3^{\text {rd }}$ (Ed.), New York: Alfred A. Knopf.

[34] Isard, W. (1976), Methods of Regional Analysis, $10^{\text {th }}$ Printing. Cambridge, MA: The M.I.T. Press. 
Apendix 1. Population Growth and Change of Saudi Regions, 1992 and 2010.

\begin{tabular}{|c|c|c|c|c|c|c|}
\hline \multirow[t]{2}{*}{ Region } & \multicolumn{2}{|c|}{ Population ('000) } & \multicolumn{2}{|c|}{ Percent Share } & \multicolumn{2}{|c|}{$\begin{array}{c}\text { Change } \\
(1992-2010)\end{array}$} \\
\hline & 1992 & 2010 & 1992 & 2010 & Total & Percent \\
\hline Riaydh & 3,835 & 6,777 & $23 \%$ & $25 \%$ & 2,942 & $77 \%$ \\
\hline Makkah & 4,468 & 6,915 & $26 \%$ & $25 \%$ & 2,447 & $55 \%$ \\
\hline Madinah & 1,085 & 1,778 & $6 \%$ & $7 \%$ & 693 & $64 \%$ \\
\hline Qassim & 751 & 1,216 & $4 \%$ & $4 \%$ & 465 & $62 \%$ \\
\hline Eastern Province & 2,576 & 4,106 & $15 \%$ & $15 \%$ & 1,530 & $59 \%$ \\
\hline Aseer & 1,340 & 1,913 & $8 \%$ & $7 \%$ & 573 & $43 \%$ \\
\hline Tabuk & 486 & 792 & $3 \%$ & $3 \%$ & 305 & $63 \%$ \\
\hline Hail & 411 & 597 & $2 \%$ & $2 \%$ & 186 & $45 \%$ \\
\hline Northern Borders & 229 & 321 & $1 \%$ & $1 \%$ & 91 & $40 \%$ \\
\hline Jazan & 866 & 1,365 & $5 \%$ & $5 \%$ & 499 & $58 \%$ \\
\hline Najran & 301 & 506 & $2 \%$ & $2 \%$ & 205 & $68 \%$ \\
\hline Baha & 332 & 412 & $2 \%$ & $2 \%$ & 80 & $24 \%$ \\
\hline Jouf & 268 & 440 & $2 \%$ & $2 \%$ & 172 & $64 \%$ \\
\hline Saudi Arabia & 16,948 & 27,137 & $100 \%$ & $100 \%$ & 10,189 & $60 \%$ \\
\hline
\end{tabular}

Source: Ministry of Economic and Planning, Central Department of Statistics and Information, 1992 \& 2010 - calculated by authors.

Appendix 2. Employment Growth and Change of Saudi Regions, 1992 and 2010.

\begin{tabular}{|c|c|c|c|c|c|c|}
\hline \multirow[t]{2}{*}{ Region } & \multicolumn{2}{|c|}{ Employment ('000) } & \multicolumn{2}{|c|}{ Percent Share } & \multicolumn{2}{|c|}{$\begin{array}{c}\text { Change } \\
(1992-2010)\end{array}$} \\
\hline & 1992 & 2010 & 1992 & 2010 & Total & Percent \\
\hline Riaydh & 1,325 & 2,267 & $27 \%$ & $28 \%$ & 942 & $71 \%$ \\
\hline Makkah & 1,362 & 2,148 & $28 \%$ & $26 \%$ & 785 & $58 \%$ \\
\hline Madinah & 262 & 476 & $5 \%$ & $6 \%$ & 214 & $82 \%$ \\
\hline Qassim & 203 & 373 & $4 \%$ & $5 \%$ & 170 & $84 \%$ \\
\hline Eastern Province & 861 & 1,236 & $18 \%$ & $15 \%$ & 375 & $44 \%$ \\
\hline Aseer & 295 & 534 & $6 \%$ & $7 \%$ & 239 & $81 \%$ \\
\hline Tabuk & 130 & 216 & $3 \%$ & $3 \%$ & 85 & $65 \%$ \\
\hline Hail & 94 & 167 & $2 \%$ & $2 \%$ & 73 & $77 \%$ \\
\hline Northern Borders & 47 & 71 & $1 \%$ & $1 \%$ & 24 & $52 \%$ \\
\hline Jazan & 145 & 308 & $3 \%$ & $4 \%$ & 163 & $113 \%$ \\
\hline Najran & 64 & 129 & $1 \%$ & $2 \%$ & 65 & $101 \%$ \\
\hline Baha & 62 & 116 & $1 \%$ & $1 \%$ & 53 & $86 \%$ \\
\hline Jouf & 64 & 108 & $1 \%$ & $1 \%$ & 44 & $69 \%$ \\
\hline Saudi Arabia & 4,914 & 8,148 & $100 \%$ & $100 \%$ & 3,234 & $66 \%$ \\
\hline
\end{tabular}

Source: Ministry of Economic and Planning, Central Department of Statistics and Information, 1992 \& 2010 - calculated by authors. 
AppendiX 3. Economic Sectors of Saudi Regions, 1992 and 2010

\begin{tabular}{|c|c|c|c|c|c|c|}
\hline \multirow[t]{2}{*}{ Economic Sectors } & \multicolumn{2}{|c|}{ Sector (‘000) } & \multicolumn{2}{|c|}{ Percent Share } & \multicolumn{2}{|c|}{$\begin{array}{c}\text { Change } \\
(1992-2010)\end{array}$} \\
\hline & 1992 & 2010 & 1992 & 2010 & Total & Percent \\
\hline All Sectors & 4,914 & 8,148 & $100 \%$ & $100 \%$ & 3,234 & $66 \%$ \\
\hline Primary Sector & 456 & 418 & $9 \%$ & $5 \%$ & -38 & $-8 \%$ \\
\hline Goods Sector & 1,196 & 1,578 & $24 \%$ & $19 \%$ & 382 & $32 \%$ \\
\hline Service Sector & 3,263 & 6,152 & $66 \%$ & $76 \%$ & 2,890 & $89 \%$ \\
\hline Agriculture \& related activities & 379 & 331 & $8 \%$ & $4 \%$ & -48 & $-13 \%$ \\
\hline Petroleum \& Minerals & 77 & 87 & $2 \%$ & $1 \%$ & 9 & $12 \%$ \\
\hline Manufacturing & 398 & 528 & $8 \%$ & $6 \%$ & 130 & $33 \%$ \\
\hline Electricity, Gas \& Water & 54 & 85 & $1 \%$ & $1 \%$ & 32 & $59 \%$ \\
\hline Construction & 744 & 965 & $15 \%$ & $12 \%$ & 220 & $30 \%$ \\
\hline Trade (Wholesale \& Retail) & 600 & 1,402 & $12 \%$ & $17 \%$ & 802 & $134 \%$ \\
\hline Tourism (Restaurants \& Hotels) & 97 & 244 & $2 \%$ & $3 \%$ & 147 & $153 \%$ \\
\hline $\begin{array}{l}\text { Transportation, Storage \& } \\
\text { Communication }\end{array}$ & 201 & 375 & $4 \%$ & $5 \%$ & 174 & $87 \%$ \\
\hline Banking \& Insurance & 47 & 98 & $1 \%$ & $1 \%$ & 51 & $107 \%$ \\
\hline Real Estate \& Business & 194 & 312 & $4 \%$ & $4 \%$ & 118 & $61 \%$ \\
\hline General Administration & 1,021 & 1,540 & $21 \%$ & $19 \%$ & 519 & $51 \%$ \\
\hline Education & 417 & 887 & $8 \%$ & $11 \%$ & 470 & $113 \%$ \\
\hline Health & 188 & 330 & $4 \%$ & $4 \%$ & 142 & $76 \%$ \\
\hline Community \& Social Services & 112 & 170 & $2 \%$ & $2 \%$ & 59 & $52 \%$ \\
\hline Private Households Services & 376 & 784 & $8 \%$ & $10 \%$ & 408 & $108 \%$ \\
\hline International Organizations & 8 & 9 & $0 \%$ & $0 \%$ & 1 & $11 \%$ \\
\hline
\end{tabular}

Source: Ministry of Economic and Planning, Central Department of Statistics and Information, 1992 \& 2010 - calculated by authors.

Appendix 4. Typology of Saudi Regional Economic Structures

Riyadh

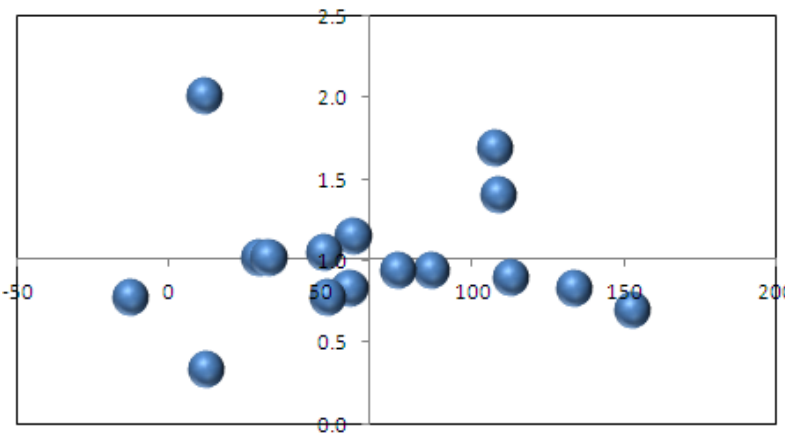

Makkah

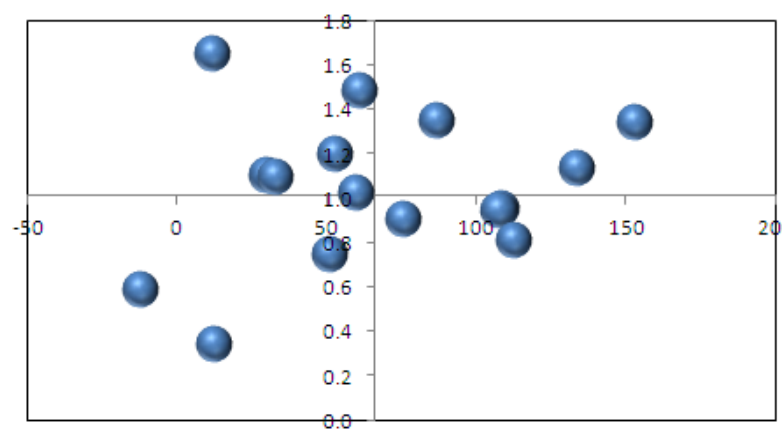



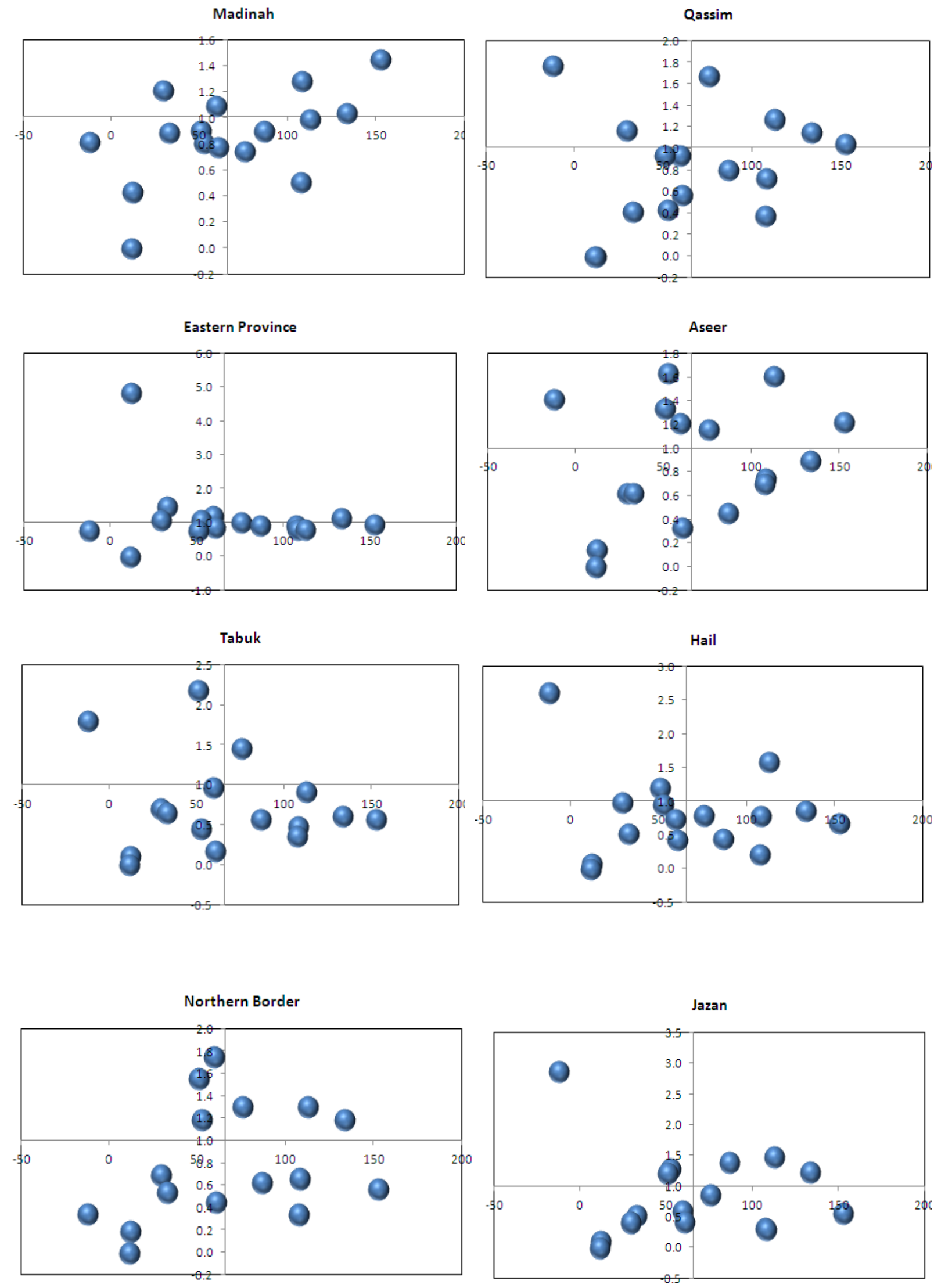

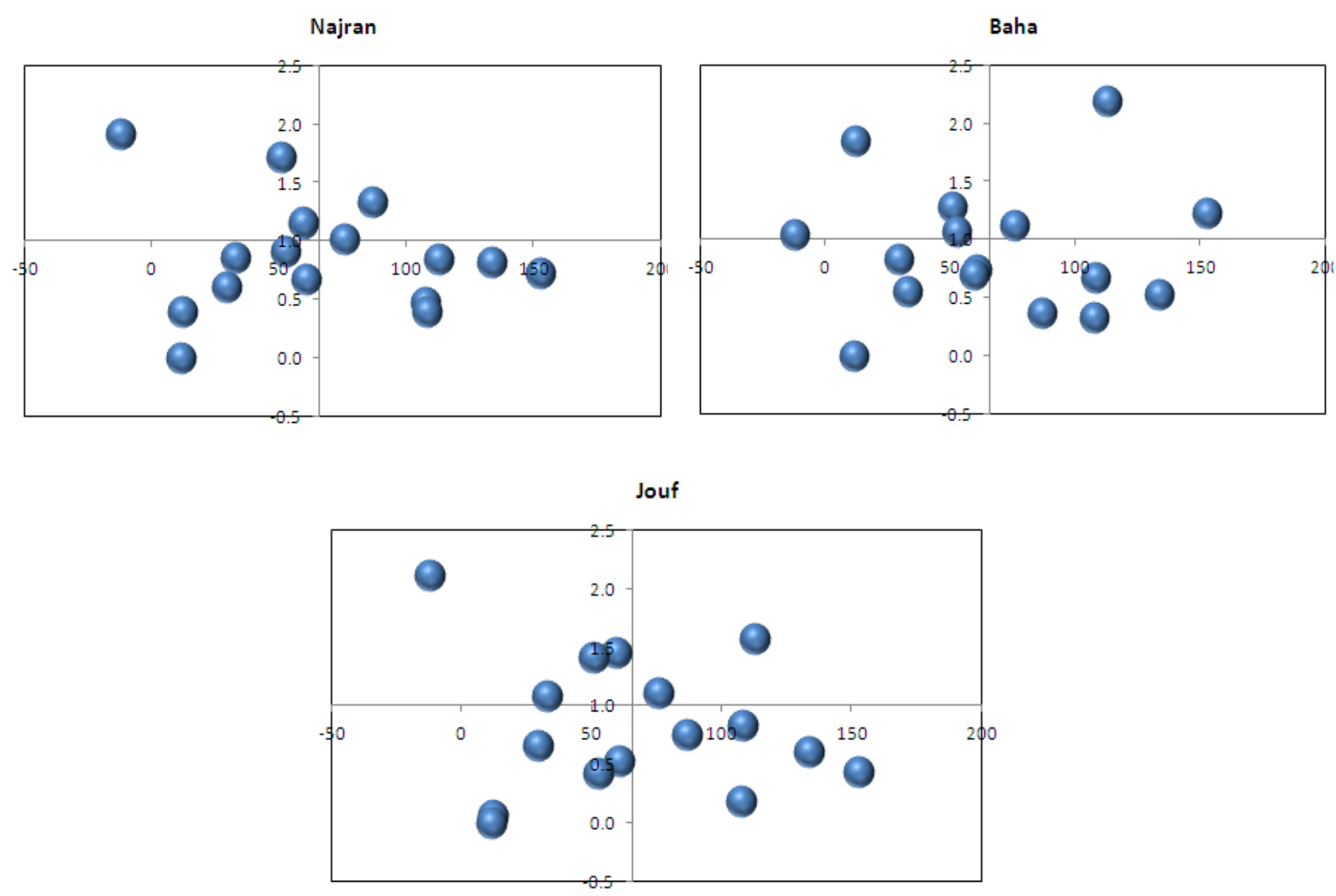


\section{نحو تتمية اقتصادية إقليمية متوازنة: المملكة العربية السعودية كحالة دراسية عبد الكريم خلف الحواش و فايز سعد الشهري قسم التخطيط الحضري والإقليهي، كلية العدارة والتخطيط، جامعة الدمام، المملكة العربية السعودية ahowaish@ud.edu.sa}

الدستخلص. على الرغم من كل الجهود التي تبذلها الحكومة السعودية على جميع المستويات لتعزيز التتمية الاقتصادية المتوازنة

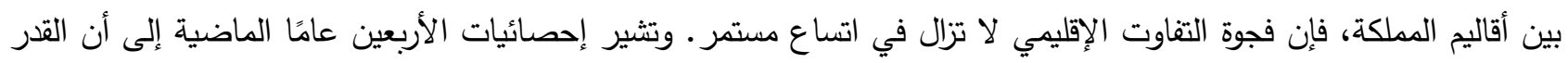

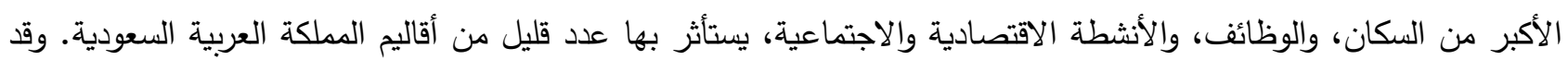

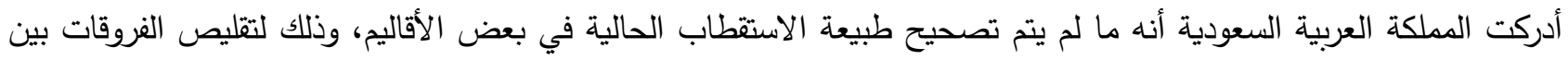

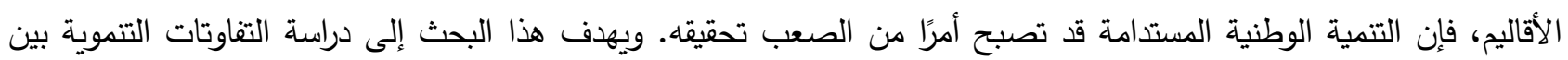

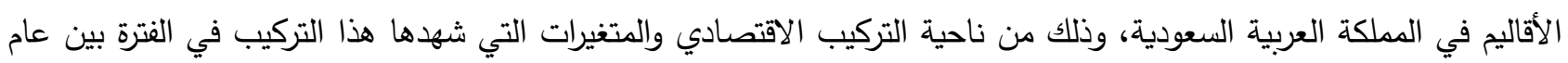
1992 وعام 2010م. وتحديدًا، فإن هذا البحث يهدف للتعرف على إمكانات التتمية الاقتصادية لأقاليم المملكة، والمزايا التتافسية لهذه الأقاليم لتحقيق تتمية اقتصادية متوازنة لجميع أقاليم المملكة. 